\title{
SERVICE LEADERSHIP EMERGENCE THROUGH SERVICE-LEARNING INTERNSHIPS IN HONG KONG
}

Robin Stanley Snell, Maureen Yin-Lee Chan, Crystal Xinru Wu, and Constance Wing-Yee Chan

\section{Abstract}

This article is about a Hong Kong-based summer internship program designed to foster service leadership attributes through service-learning. We report research based on interviews with interns and their partner organization representatives (PORs) and on written assignments as required by the program. We also report how the research informed the redesigning of the program. The research identified factors that support service leadership emergence, including servant leadership by PORs; appropriate intern responsibilities; support from other stakeholders; and interns'possession of a secure knowledge foundation. Conservation of resources (COR) theory underpins our explanation of how these factors enhance service leadership emergence, while self-determination theory (SDT) also explains the impact of servant leadership by PORs. We conclude by explaining the subsequent actions that have been taken to leverage the supportive factors.

\section{Introduction}

Internships involve students' practical engagement in workplace settings (Beard, 2007; Holyoak, 2013). However, the educational quality of internships varies considerably. Expediency can prevail over educational goals (Scheuer \& Mills, 2016), with interns confined to routine clerical duties (Coco, 2000; Ross \& Elechi, 2002) or even to production line work (Smith \& Chan, 2015). When educational purposes prevail, interns are assigned knowledge-work assignments with reasonable time frames and task significance (i.e., social and organizational impact) and receive guidance, support, and meaningful feedback (D’Abate, Youndt, \& Wenzel, 2009; Rothman, 2003, 2007; Woodside, 2017).

Among educationally oriented internships, some emphasize applying knowledge directly related to the degree major (Knemeyer \& Murphy, 2002; Ross \& Elechi, 2002; Zhang, 2013), while others emphasize opportunities to develop personal, interpersonal, and leadership skills (Beard, 2007; Chow \& Lam, 2015; Clark, 
2003; Cook, Parker, \& Pettijohn, 2004; Degravel, 2011). Our article investigates the latter, developmental type in the form of an internship program ("the internship program”) organized by a Hong Kong-based university ("University X") that offers opportunities to practice service leadership attributes in community organizations (Chow \& Lam, 2015; Chung, 2012; Shek \& Leung, 2015). Our research sought to add theoretical understanding and practical insight (Woodside, 2017) on how to provide empowerment and resource support for the interns to practice as emerging service leaders.

In the next section, we introduce the concept of service leadership (Chow \& Lam, 2015; Chung, 2012; Shek \& Leung, 2015) and explain the aims and design of the internship program. There follows a section on theoretical model development, covering servant leadership (Chiniara \& Bentein, 2016; Spears, 2004), self-determination theory (SDT) (Bringle, Studer, Wilson, Clayton, \& Steinberg 2011; Chiniara \& Bentein, 2016; Deci, 1971; Deci \& Ryan, 2000), and conservation of resources (COR) theory (Hobfoll, 1989). We explain two emergent conceptual models of service leadership emergence. The first model is based on SDT and proposes that if partner organization representatives (PORs) act as servant leaders, they address interns' needs for autonomy, competence, and relatedness (Deci \& Ryan, 2000) and thereby create conditions for interns to emerge as service leaders. The second model draws on COR theory (Hobfoll, 1989) to represent how various factors can energize and affirm interns as they practice service leadership attributes, namely enactment of servant leadership by PORs; assignment to interns of appropriate service leadership responsibilities; support by stakeholders, such as other interns, service recipients, and regular employees; and a secure foundation of knowledge for the interns.

A methodology section explains our research study, in which we collected data from all 16 interns who joined the internship program in 2014 and from PORs at all 10 community organizations hosting internships that summer. In our findings' section, we relate case examples of service leadership emergence and otherwise to both the SDT model and the COR model. In our discussion and conclusions section, we emphasize practical implications, discuss generalizability to contexts beyond the host community organizations, and acknowledge the limitations of the research.

\section{Program Background}

\section{The Concept of Service Leadership}

The launching of the internship program was inspired by the idea that service leadership is an appropriate model for advanced economies, in which most employees work in service industries (Fung, 2015). Excellent service requires diagnosing, creating, and improvising solutions to meet distinctive needs of service recipients (Grönfeldt \& Strother, 2006). However, workplace cultures that assume top-down leadership, unilateral command and control, layers of hierarchy, and subordinate obedience persist as legacies of the "factory era" (Atkinson, 2004, p. 105). Service-based or knowledge-intensive organizations require radically different leadership 
approaches (Atkinson, 2004; Rost, 1991) that emphasize collaboration and mutual influence (Chung, 2012; Debeljuh \& Destefano, 2005; Rost, 1991, 1994). In service leadership, frontline servers can propose, design, and improvise services that anticipate and respond to recipients' needs (Chung, 2012; Fung, 2015).

\section{The Internship Program}

Overall structure. The internship program began in 2013 and is open to students from all majors at University X. It became credit-bearing in 2016. Between 12 and 16 full-time internships at Hong Kong-based community partner organizations have been offered during each summer vacation. At the time of this research, the internship program was managed by a field coordinator working at "Unit $S$," which is responsible, university-wide, for coordinating service-learning-based courses or programs (see Howard, 2001). Interns received a stipend, conditional upon completing the internship and all the associated coursework assignments. With the exception of interns at one partner organization that paid the stipend itself(Site 9 in Table 2, see later), all other interns received the stipend from an independent charity that promotes service leadership education.

Aims. The internship program aims to help interns develop 10 service leadership attributes. Table 1 maps these attributes against broader outcome domains for service leadership education. The latter, according to Shek and Leung (2015), comprise intrapersonal competencies such as problem-solving abilities (Ayres \& Malouff, 2007) and emotional intelligence (George, 2000; Nelis et al., 2011); interpersonal competencies (Segrin \& Taylor, 2007) such as relationship-building; plus moral character, caring disposition, self-leadership, and continuous self-improvement. 
Table 1

Service Leadership Attributes Targeted by the Program

\begin{tabular}{ll}
\hline $\begin{array}{c}\text { Service leadership attributes targeted by } \\
\text { the internship program }\end{array}$ & $\begin{array}{c}\text { Service leadership developmental domains (Shek } \\
\text { \& Leung, 2015) }\end{array}$ \\
\hline Anticipating and solving problems & Intrapersonal competencies \\
\hline $\begin{array}{l}\text { Expressing original and constructive } \\
\text { opinions }\end{array}$ & \\
\hline
\end{tabular}

Project coordination skills

\begin{tabular}{ll}
\hline Active listening & Interpersonal competencies \\
\hline $\begin{array}{l}\text { Contributing to cohesiveness \& close } \\
\text { relationships }\end{array}$ & \\
\hline Influencing others & Moral character \\
\hline Undertaking delegated responsibilities & \\
\hline Civic engagement & Caring disposition \\
\hline Caring disposition & Self-leadership \& continuous self-improvement \\
\hline Committing to continuous improvement
\end{tabular}

Placement structures. From 2014 onward, the internships have lasted eight weeks, full time. They have been individual-based, unlike the team-based service leadership internships arranged by some other universities (e.g., Chow \& Lam, 2015). Nonetheless, if two or more interns in the program are based at the same site, they may undertake some tasks together. At their various sites, interns in the program may also collaborate with interns from other programs and universities.

Obtaining placements and enlisting PORs. Unit $S$ has sought, with varying success, to enlist PORs who are willing to engage as co-educators (Godfrey, Illes, \& Berry, 2005; Kenworthy-U'Ren, 2003; Papamarcos, 2005 , p. 330) by providing full supervisory support, including induction, training, coaching, guidance, and constructive feedback.

Mini-missions. Prior to their commencement, Unit $S$ works with PORs to draft provisional mini-mission statements for each internship. These are intended to ensure that the interns undertake projects that make a difference and empower them to practice service leadership attributes. For example, in 2014, intern M1 set up a surplus vegetable collection network, promoted "food cherishing" and "zero food waste" programs in the 
community, and organized an exhibition based on associated community research. Interns F6 and F7 designed, promoted, and organized exercise-related community events for the elderly. It is intended that interns revise and update their mini-missions as their work progresses, in consultation with their POR(s) and Unit S.

Selecting and matching interns. Unit $S$ selects students for the internship program on the basis of written applications, interviews, and team exercises. Criteria for selection include knowledge about and enthusiasm for civic engagement and prior service-learning experience. Selected students may attend a second screening interview by PORs and are matched with host sites on the basis of their preferences, prior experience, and cognate subject knowledge.

Preparation and review workshops. Prior to internship commencement, a preparatory workshop introduces the 10 targeted service leadership attributes (see Table 1) and includes discussions about the mini-missions. A one-day interim plenary review workshop is held half-way through the internship period. From 2015 onward, a plenary review workshop has been held at the end of the internship period.

Written and oral reflections. Interns are required to submit individual learning diaries on a fortnightly basis. These include reflections about their service leadership engagement, accounts of progress on mini-missions, and analyses of salient aspects of their host organization, such as its vision, mission, culture, strengths, weaknesses, opportunities, threats, and directions for improvement. Each intern also submits a final reflective report, summarizing developmental engagement and areas of leadership transformation, identifying future developmental needs, self-evaluating performance on mini-missions, and suggesting ways to improve the internship experience. In addition, students make oral presentations at the interim and review workshops.

\section{Theoretical Background, Research Questions, and Model Development}

In this section, we review literature on servant leadership, self-determination theory, and conservation of resources theory and present propositions and two models up front, which in practice evolved through constant comparisons between emerging research findings and pre-existing theoretical concepts (Hallberg, 2006).

\section{How PORs' Servant Leadership May Support Interns' Emergence as Service Leaders}

Servant leadership appears to be an appropriate leadership approach for PORs. There are similarities and differences between the concepts of service leadership and servant leadership (Shek, Chung, \& Leung, 2015). Both involve "a strong sense of care” (Shek \& Chung, 2015, p. 230), "an active and proactive attitude that modern society expects from service providers and leaders” (Zhou, Chan, \& Mickleborough, 2015, p. 137), and "a lifelong journey that includes discovery of one's self, a desire to serve others, and a commitment to lead" 
(Hoshmand, 2015, p. 18, quoting Greenleaf, 1977). Yet whereas service leaders serve "everybody, everywhere, and every day" (Zhou et al., 2015, p. 137), servant leaders focus on putting followers first (Shek \& Leung, 2015, p. 4).

Servant leaders meet the psychological needs of their followers by empowering them and providing them with direction, emotional support, feedback, and resources (Chiniara \& Bentein, 2016; Grant, 2013; Greenleaf, Beazley, Beggs, \& Spears, 2003; Liden, Wayne, Zhao, \& Henderson, 2008; Sabbaghi, Cavanagh, \& Hipskind, 2013; Spears, 2010; Trompenaars \& Voerman, 2010; van Dierendonck, 2011). Enlisting PORs as co-educators is consistent with the expectation that they should act as servant leaders for the interns. However, Unit S only made this conceptual connection after reading Chiniara and Bentein (2016), and prior to 2016, absence of conceptual clarity may have impeded attempts to establish appropriate developmental contracts (Stuart, 1978) with PORs and interns. It turned out that some PORs did not adopt the roles of co-educator and servant leader. Our first research question, RQ1, is, How does servant leadership enacted by PORs contribute to interns' emergence as service leaders during the internship program?

\section{Self-Determination Theory (SDT)}

SDT holds that autonomous motivation for growth through tackling challenges depends on satisfying psychological needs for autonomy, competence, and relatedness (Deci, 1971; Deci \& Ryan, 2000; Deci, Vallerand, Pelletier, \& Ryan, 1991, pp. 327-328). Figure 1 derives from Chiniara and Bentein, who studied the impact of servant leadership by supervisors on the need satisfaction and work performance of regular employees in a high technology company. Notwithstanding the different context of our own research, we shall next develop some matching propositions about how servant leadership (Liden et al., 2008) by PORs increases interns' readiness to practice service leadership by addressing their needs for autonomy, competence, and relatedness. 


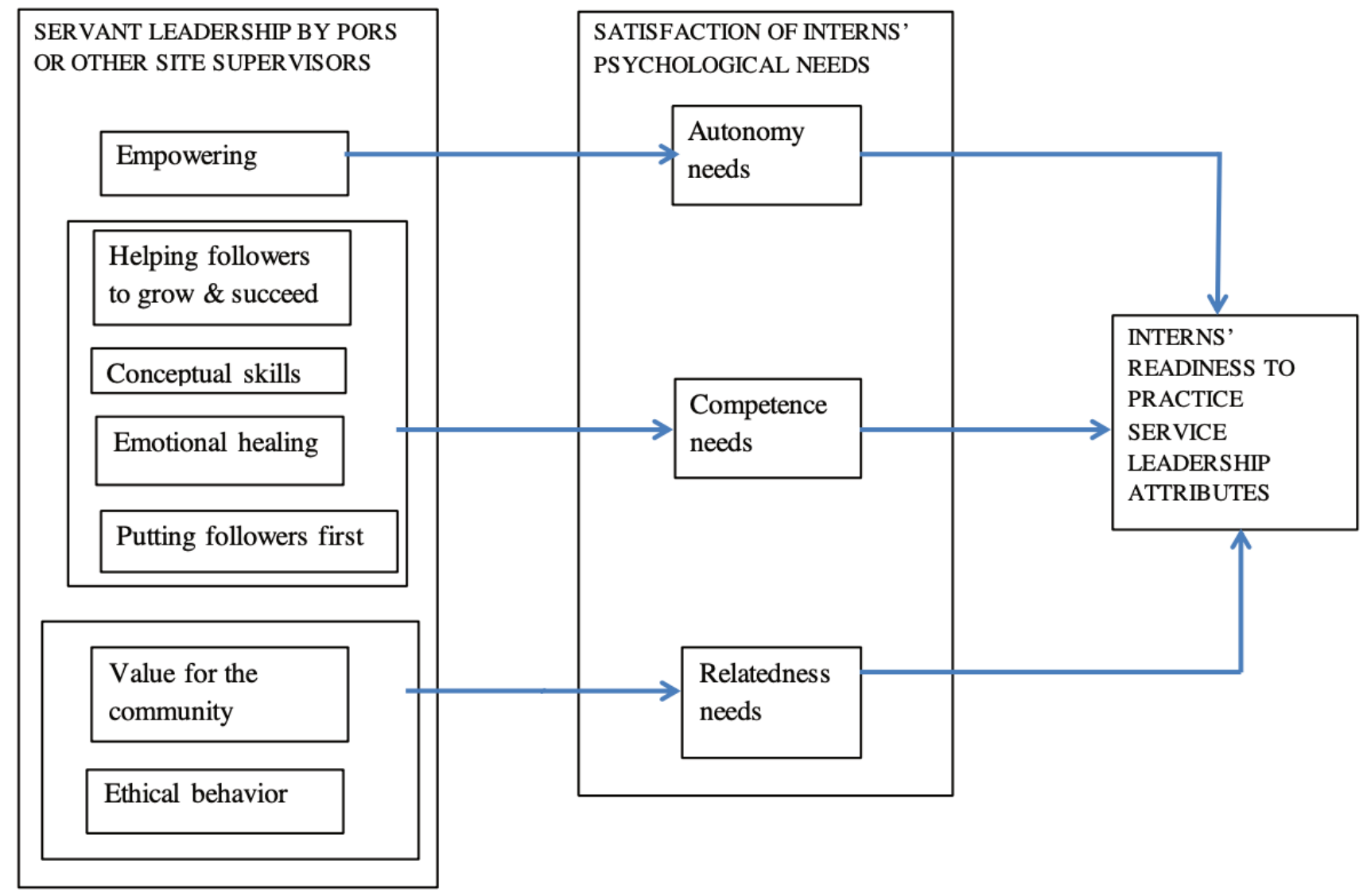

Figure 1. How Servant Leadership May Increase the Readiness of Interns to Practice Service Leadership.

Autonomy. This involves the self-perception that one is free to originate actions that are self-governed, selfendorsed, and self-owned (Ryan \& Deci, 2006). According to SDT, people feel some autonomy, even when requested to act in particular ways, if they value those actions and regard the requests as reasonable (Gagné \& Deci, 2005). People feel more autonomy when they also regard their actions as congruent with their overall values and beliefs, and they feel the strongest sense of autonomy when pursuing actions for their own sake (Ryan \& Deci, 2006, p. 1563). Empowering followers is a key facet of servant leadership. Servant leaders empower followers by entrusting them with authority and discretion and by encouraging them to exercise voice, thereby meeting autonomy needs (Chiniara \& Bentein, 2016; Liden et al., 2008). Hence:

P1. PORs increase interns' developmental engagement by assigning them meaningful tasks with delegated authority and inviting their ideas and suggestions, i.e., by empowering them.

Competence. Felt competence equates to self-efficacy (Bandura, 1986) in that it entails the belief that one is effective and mastering salient capabilities. Besides being a prerequisite for psychological health and wellbeing (Deci, 1971), felt competence enhances vitality (Ryan \& Deci, 2008; Sheldon, Ryan, \& Reis, 1996). We consider that four facets of servant leadership (Liden et al., 2008) are salient in addressing followers' competence needs (Chiniara \& Bentein, 2016). The first, helping followers to grow and succeed, involves providing 
them opportunities to enhance skills that match their interests and aspirations. Second, putting followers first involves prioritizing followers' development over the expediency of using them as a "pair of hands." Third, followers' felt competence can be maintained, even when the latter cannot solve a particular problem independently, if a servant leader draws on conceptual skills to diagnose appropriate interventions to augment (and not dismiss) followers' efforts. Fourth, a servant leader may enact emotional healing to help recover followers' self-esteem, if, for example, the latter are dismayed because of their failure to achieve something (Liden et al., 2008). Hence:

P2. PORs increase interns' developmental engagement by (a) aligning assignments with their interests and aspirations, that is, helping interns grow and succeed; (b) prioritizing interns' interests over expediency, that is, putting interns first; (c) providing timely interventions based on expert diagnosis of service requirements, that is, drawing on conceptual skills; and (d) helping interns recover self-esteem after mishaps, that is, emotional healing.

Relatedness. This need involves "the universal propensity to interact with, be connected to, and experience caring for other people" (Baumeister \& Leary, 1995; Deci \& Vansteenkiste, 2004, p. 25). Opportunities to work interdependently with others and develop a sense of belongingness to a team encourages autonomous motivation (Gagné \& Deci, 2005, p. 355; Van Knippenberg \& Van Schie, 2000). The quality of interpersonal interaction is important in meeting relatedness needs and requires a workplace climate characterized by psychological safety and high trust (Ehrhart, 2004; Schaubroeck, Lam, \& Peng, 2011). Servant leaders help to create and sustain such a climate through ethical behavior, treating subordinates fairly and respectfully (Chiniara \& Bentein, 2016; Liden et al., 2008). A servant leader's self-restraint and impartiality are conducive to conflict resolution (Jit, Sharma, \& Kawatra, 2016). Another relatedness factor extends to bonds between organization members and the wider community. Servant leaders meet followers' relatedness needs by leading them in serving the community (Chiniara \& Bentein, 2016; Liden et al., 2008). This is especially important with the internship program. Hence:

P3. PORs increase interns' developmental engagement by (a) resolving conflicts in a fair and respectful manner, that is, ethical behavior; and (b) exemplifying community engagement.

\section{Contextual and Personal Factors}

RQ2 asks, How do appropriate intern responsibilities, stakeholder support, and a secure knowledge foundation support interns' developmental engagement as emerging service leaders? Concerning interns' actions in exercising responsibility and discretion and in relating to others (Avolio \& Hannah, 2008; Cunliffe, 2009), RQ3 asks, How and why do interns go about enacting (or otherwise) their own emergence as service leaders when presented with opportunities? The following section shall explain COR as a background theory for making sense of the interplay of contextual and personal factors. 


\section{Conservation of Resources (COR) Theory}

According to COR theory (Hobfoll, 1989, 2002), people are motivated to obtain, maintain, and develop resources. Job-based resources, such as formative feedback, social support, autonomy, and developmental opportunities, foster work engagement (Bakker \& Demerouti, 2008; Halbesleben \& Wheeler, 2008; Schaufeli \& Salanova, 2005). Hobfoll (1989) identified personal characteristics (e.g., personal traits, skills), conditions (e.g., roles, supporting systems), and energies (e.g., time, money) as three kinds of resources.

Intended conditions. Unit $S$ intends that interns are assigned meaningful responsibilities that involve creativity and analysis, organizing people and events, working in teams, and contact with the community. Meaningful roles of this kind, in contrast with back-up clerical or technical tasks, endow high-quality conditions for the interns, enabling developmental engagement as emerging service leaders as they develop close and constructive social bonds with PORs, peers, and the community. Intended supporting systems include servant leadership behavior by PORs in addressing interns' situational needs (Hobfoll, 1985), thus building and reinforcing their readiness to practice service leadership. Intended conditions also include support by co-workers in sharing information, giving advice, and offering encouragement.

Valued personal characteristics. Unit $S$ intends that screening and preparation ensure that by the time students commence their internships, they already have a foundation of personal characteristics that can help them overcome obstacles to practicing service leadership. This includes prior service-learning experience, understanding of service leadership concepts, and salient domain-specific knowledge and skills. During the internships, interns increase their resources if they practice service leadership effectively.

Energies. From our earlier discussion of SDT, we infer that the most salient energies for interns in practicing service leadership derive from the experience that their needs for empowerment, competence, and relatedness are being met.

Spirals of resource gain or loss. Hobfoll (1989) argued that stress occurs under three situations: (a) threat of resource loss; (b) actual loss of a resource; or (c) lack of resource gain after resource investment. According to COR theory, people seek resource surpluses when they are not confronted with stressors (Hobfoll, 1989). Also, COR theory assumes the model of an embedded spiral (Hobfoll \& Lilly, 1993; Hobfoll, 2001). Thus, if an individual has resources, he or she is better able to gain more resources, such that "gain begets further gain.” A favorable scenario for an intern involves appropriate responsibilities, a secure foundation of knowledge, servant leadership by PORs, and stakeholder support, all backing their efforts to acquire desired personal characteristics in the form of service leadership attributes. Ideally, these resources yield further resource gains by increasing interns' energy and readiness to address and overcome challenges that arise during the internships. Developmental engagement is likely to enhance interns' personal characteristics, that is, service leadership attributes, consequently increasing their energy resources. For example, interns may observe their own practical and social impacts, leading to a sense of affirmation that, in turn, increases their self-efficacy and hence their willingness and ability to tackle further challenges. Thus, resource gains in terms of energy and personal characteristics give rise to further resource gains (Hobfoll \& Lilly, 1993). 
Preventing spirals of loss. Conversely, if an individual lacks resources, he or she is vulnerable to resource loss, with an ensuing "loss begets further loss” spiral (Hobfoll \& Lilly, 1993; Hobfoll, 2001). It is likely also that during internships, students will make mistakes and encounter mishaps, not least because they are typically newcomers to their host organization and to the community serviced by that organization. Psychological stress entailed by unfamiliar challenges may give rise to resource loss unless desirable conditions, such as servant leadership by PORs, stakeholder support, and/or possession of sufficiently developed personal characteristics, replenish an intern's reservoir of resources. This will enable the intern to recover and to rediscover energy to plan and engage in remedial and constructive actions, thus forestalling a spiral of losses. However, if such desirable conditions and/or personal characteristics are absent, a spiral of losses may ensue, with interns losing energy and confidence, and instead "withdrawing into their shell."

A resource gain model. Depicted in Figure 2, the spiral of resource gains assumes a cycle of readiness, engagement, recovery (if necessary), affirmation, and increased self-efficacy. The following proposition summarizes our discussion about the role of contextual and personal factors.

P4. Interns' emergence as service leaders is induced and maintained by (a) appropriate task assignments that stretch interns' service leadership attributes; (b) PORs' servant leadership; (c) stakeholder support through sharing information, ideas, advice, and feedback; (d) interns' possession of a foundation of knowledge and experience that confers a sense of security; and (e) interns' willingness to address and overcome challenges.

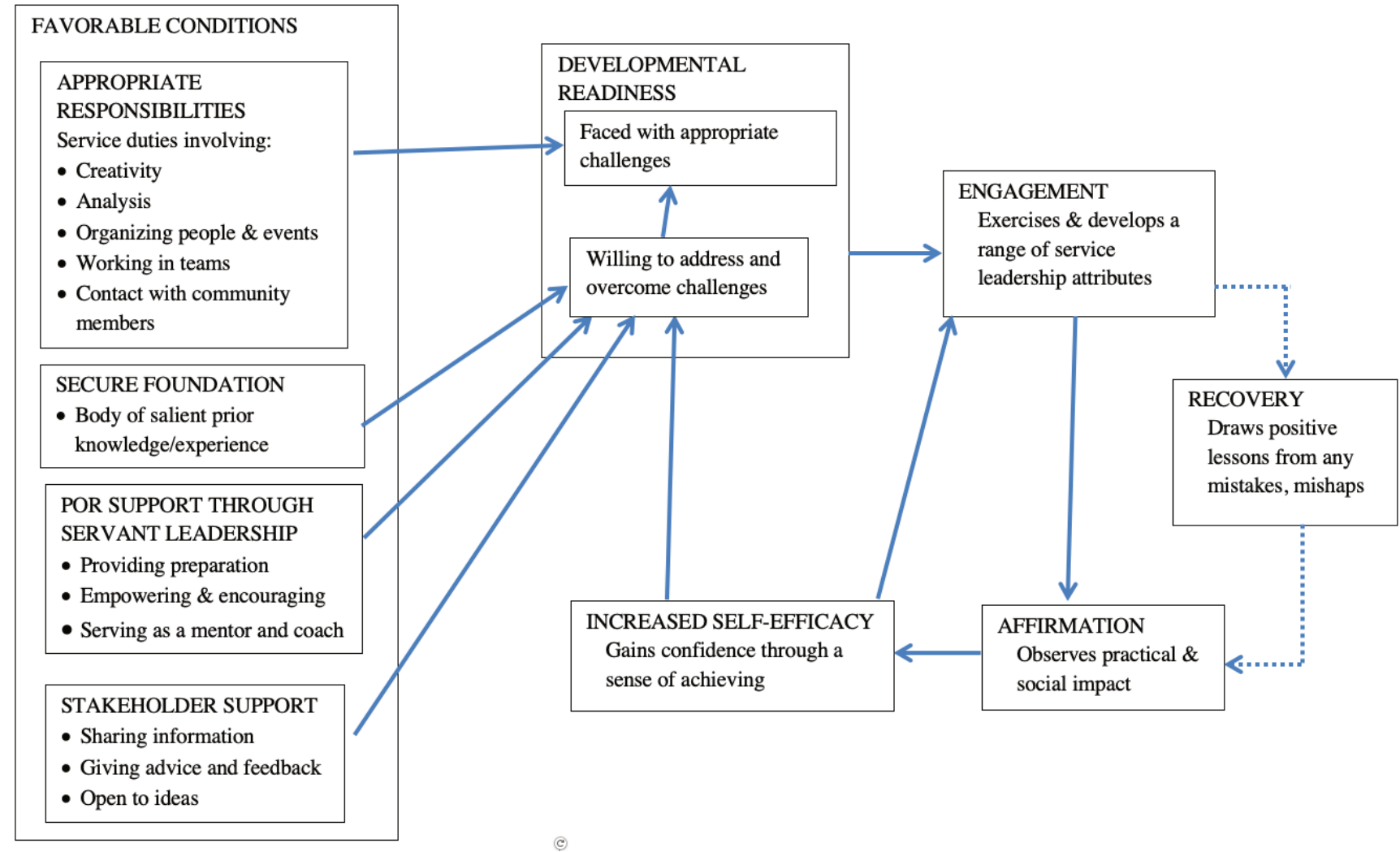

Figure 2. Expanded Model of Interns' Developmental Engagement as Emerging Service Leaders. 


\section{The Research}

We conducted exploratory research with the pragmatic purpose (Cherryholmes, 1992) of improving the internship program.

\section{Data Collection}

All 16 internships undertaken in the summer of 2014 were investigated. Internship sites, PORs, and students' particulars are listed in Table 2, along with code names. Data were collected from interns and PORs via face-toface interviews and documentary sources. This multi-source database enabled us to triangulate and cross-corroborate information (Jonsen \& Jehn, 2009) and thereby enhance analytical validity (Creswell, 2013; Solansky, 2015). 
Table 2.

Host Sites and Informants

\begin{tabular}{|c|c|c|c|c|c|}
\hline \multirow{2}{*}{$\begin{array}{l}\text { Site } \\
\text { no. }\end{array}$} & \multirow{2}{*}{ Host's mission domain } & \multicolumn{2}{|c|}{ Code names } & \multicolumn{2}{|c|}{ Students' details } \\
\hline & & PORs & Students & Year & Major \\
\hline \multirow[b]{2}{*}{1} & \multirow[b]{2}{*}{ Elderly education } & \multirow[b]{2}{*}{$1 \mathrm{a}, 1 \mathrm{~b}$} & $\mathrm{~F} 1$ & 2 & Social science \\
\hline & & & F2 & 2 & Social science \\
\hline \multirow{2}{*}{2} & \multirow{2}{*}{ Surplus food distribution } & \multirow{2}{*}{$2 \mathrm{a}$} & M1 & 2 & Social science \\
\hline & & & F3 & 1 & Translation \\
\hline \multirow[b]{2}{*}{3} & \multirow{2}{*}{ University service-learning } & \multirow{2}{*}{$3 a, 3 b$} & $\mathrm{~F} 4$ & 2 & Philosophy \\
\hline & & & M2 & 2 & Translation \\
\hline 4 & Translation for ethnic minorities & $4 a$ & F5 & 2 & Translation \\
\hline \multirow{2}{*}{5} & \multirow{2}{*}{ Elderly recreation } & \multirow{2}{*}{$5 a$} & F6 & 2 & Social science \\
\hline & & & F7 & 2 & Social science \\
\hline \multirow[b]{2}{*}{6} & \multirow[b]{2}{*}{ Clothes recycling } & \multirow[b]{2}{*}{$6 a$} & F8 & 2 & Social science \\
\hline & & & M3 & 2 & Cultural studies \\
\hline \multirow[b]{2}{*}{7} & \multirow[b]{2}{*}{ Social enterprise corporate services } & \multirow[b]{2}{*}{$7 \mathrm{a}$} & F9 & 2 & Social science \\
\hline & & & F10 & 2 & Marketing \\
\hline 8 & Language education & $8 \mathrm{a}, 8 \mathrm{~b}$ & F11 & 2 & Social science \\
\hline 9 & Rehabilitation/outdoor development & $9 \mathrm{a}, 9 \mathrm{~b}$ & M4 & 2 & Social science \\
\hline 10 & Advocacy for refugees & $10 a, 10 b$ & $\mathrm{~F} 12$ & 2 & English \\
\hline
\end{tabular}

Interviews were guided by a pre-designed list of open-ended questions about issues, such as opportunities to practice service leadership and how on-site guidance had been provided. PORs with more than one intern were asked to comment about each intern. The interviewer sought to elicit storytelling (Boje, 2001; Gabriel, 2000) about critical incidents (Bitner, Booms, $\&$ Mohr, 1994). These interviews were tape recorded, with informants' permission, and were transcribed from Cantonese into English. Several months afterward, the first and second authors jointly conducted a 60-minute interview with an employee from Unit $S$, who had 
served as the field coordinator of the program, about all the internships in 2014 . The second author took detailed notes at that interview.

Interviews. The second author conducted face-to-face, semi-structured interviews (Kvale, 1996), each lasting 90-120 minutes, with the 16 students ( 4 males and 12 females) and with PORs from all 10 host organizations. These took place shortly before or after completion of the internships, on a one-to-one basis with the students and on a site-by-site basis with the PORs (i.e., if there were two PORs at the same site, they were interviewed together).

Documentary sources. With students' permission, fortnightly learning journals and post-internship selfreflection reports were analyzed, as were performance appraisal reports by PORs about 9 of the 16 interns.

\section{Data Analysis}

The propositions presented earlier in this article evolved during data analysis, as the authors discovered salient literatures on servant leadership, SDT, and COR theory and engaged in constant comparisons and triangulation (Leech \& Ongwuegbuzie, 2008) between accounts of interns and their PORs, theoretical insights, critical incidents, and general data patterns. Data were initially categorized according to the interview guide and then were marshalled to address the RQs and propositions. We conducted cross-site and within-site comparisons (Miles \& Huberman, 1994; Yin, 2009) to identify similarities and differences about interns' experiences. We arrived at analyses of the appropriateness of tasks undertaken by each of the 16 interns, the social context in which such tasks were undertaken, the extent to which the POR(s) served as a co-educator(s), the extent of developmental engagement by the interns, and the quality of their developmental outcomes. These analyses were aggregated into Table 3. Descriptive and critical incident examples were compiled to illustrate similarities and differences among the various internship experiences and outcomes. 


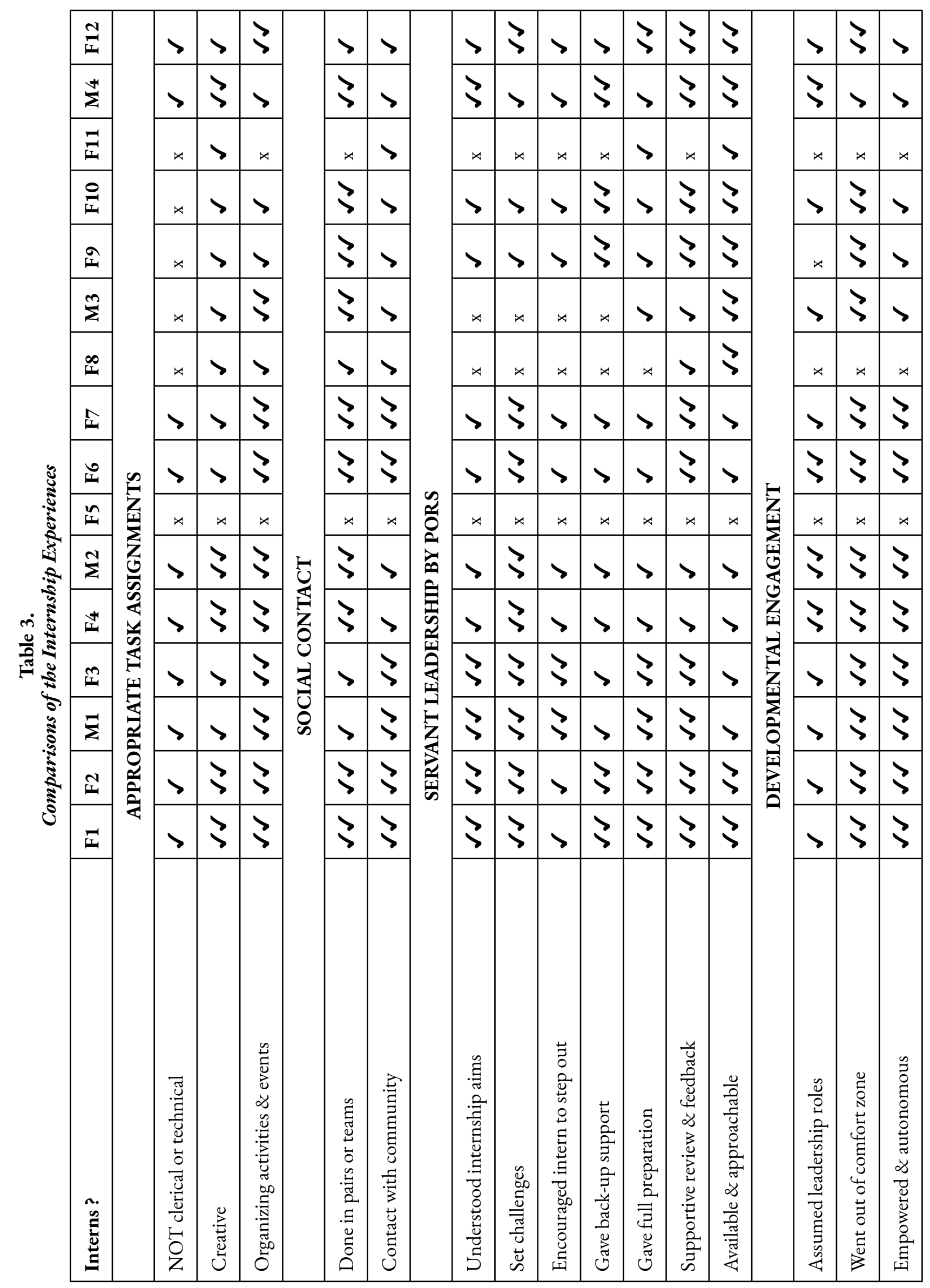




\begin{tabular}{|c|c|c|c|c|c|c|c|}
\hline$>$ & & $>$ & $>$ & 3 & 3 & $\zeta$ & \\
\hline$>$ & & $>$ & $\zeta$ & 3 & $>$ & I & \\
\hline$\star$ & & $\star$ & $\star x$ & $\star$ & $\star$ & $\star$ & \\
\hline$\zeta$ & & $>$ & $>$ & $>$ & $\zeta$ & $\zeta$ & \\
\hline 3 & & 3 & $>$ & $>$ & $\star$ & 3 & \\
\hline 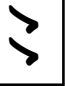 & & $>$ & $>$ & $\zeta$ & 3 & $\zeta$ & \\
\hline$\star$ & & $\star$ & $\star$ & $\star$ & $\star$ & $\star$ & \\
\hline 3 & & 3 & 3 & 3 & 3 & 3 & \\
\hline$\zeta$ & $\sum_{0}$ & $>$ & 3 & $\zeta$ & 3 & 3 & \\
\hline$\star$ & 5 & $\star$ & $\times$ & $\star$ & $\star$ & $\star$ & \\
\hline 3 & $\vec{S}$ & $>$ & 3 & 3 & 3 & 3 & \\
\hline 3 & 鱼 & 3 & 3 & 3 & $\zeta$ & 3 & \\
\hline 3 & $\begin{array}{l}0 \\
0 \\
0\end{array}$ & 3 & 3 & 3 & 3 & 3 & \\
\hline 3 & 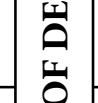 & 3 & 3 & 3 & 3 & 3 & \\
\hline 3 & 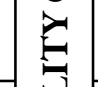 & $>$ & 3 & 3 & 3 & 3 & \\
\hline 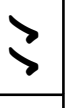 & $\vec{z}$ & $>$ & 3 & 3 & 3 & 3 & 鹿 \\
\hline 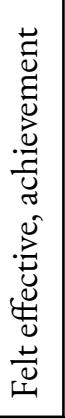 & & 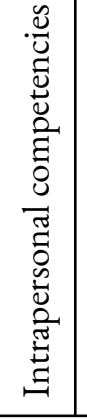 & 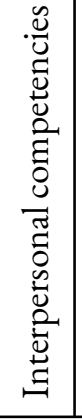 & 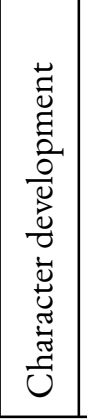 & 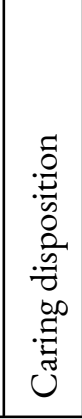 & 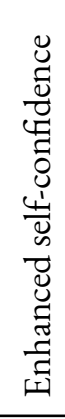 & 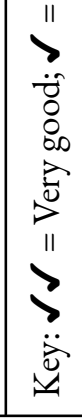 \\
\hline
\end{tabular}




\section{Findings}

\section{Differences in Developmental Engagement and Developmental Outcomes}

The bottom five rows in Table 3 broadly correspond to clusters of targeted service leadership attributes in Table 1. Ticks in these rows indicate the quality of developmental outcomes and hence the effectiveness of each internship. Among the internships, eight (those of F1, F2, F3, F4, F6, F7, M1, and M2) appeared very effective in facilitating service leadership emergence (indicated by a total of 9-10 ticks). Another five internships (those of M3, M4, F9, F10, and F12) appeared moderately effective (6-8 ticks), while the remaining three internships (those of F5, F8, and F11) appeared ineffective (no ticks). The patterns in Table 3 suggest also that these contrasting levels of perceived effectiveness may directly reflect the extent to which the interns were empowered to enact leadership roles. Thus, all eight very effective internships involved high levels of developmental engagement, indicated by high ratings (a total of 7-8 ticks) in the corresponding four rows in Table 3 . All five moderately effective internships received moderate ratings (5-6 ticks) on developmental engagement, whereas the ineffective internships received low ratings (no ticks) on developmental engagement.

\section{Impact of Appropriate Task Assignments}

Although Unit $S$ intended that the interns would be assigned challenging tasks and leadership responsibilities, the third row of Table 3 indicates that in practice, interns also performed clerical or technical work. Some PORs indicated they had initially assumed that it was acceptable to assign a predominantly clerical workload to their interns but that later on they had been persuaded otherwise. For example, POR 1a explained that an intervention by the field coordinator from Unit $S$ had convinced him to assign more challenging tasks to interns F1 and F2:

I told [the field coordinator] about our proposed assignments, and thanks to her for her frank response that our initial arrangement may not meet the aims of this program. On reflection, I realized that if they wanted simple tasks, they would not need to go through this academic program. So, I adjusted the content and degree of difficulty of the job assignments and arranged for the interns to acquire the requisite job knowledge and skills in a short time. (POR1a, interview)

It appeared that interns at some other sites were less fortunate. For example, F11 reported:

I did not have any project to lead and organize. [POR8b] seemed to forget about this aspect, so all the tasks were routine. This was not what I expected, and I have not learned much. During the first two weeks, [POR8b] talked 
with me about my areas for improvement and it was good, but in the end, I was allocated routine tasks. [POR 8a and POR 8b] seemed to forget about this program. (F11, interview)

Three rows near the top of Table 3 indicate the appropriateness of the tasks assigned to the interns. The eight apparently very effective and developmentally engaging internships (those of F1, F2, F3, F4, F6, F7, M1, and M2) also received high ratings (4-5 ticks) on task appropriateness. Among the five apparently moderately effective and developmentally engaging internships (those of M3, M4, F9, F10, and F12), ratings on task appropriateness also tended to be moderate (2-4 ticks). Among the three apparently least effective and developmentally engaging internships (those of F5, F8, and F11), ratings on task appropriateness tended to be the lowest (0-2 ticks).

More interns could provide critical incident illustrations of how they practiced service leadership attributes when allocated appropriate responsibilities. For example, F12 described a non-routine selling situation, M1 set up a surplus food collection and distributing system and conducted a trial-run with service recipients, and F2 observed and improved upon a practice for instructing elderly clients in using information technology.

\section{The Impact of the Presence or Absence of Servant Leadership by PORs}

Table 4 contrasts the espoused practices of POR $8 \mathrm{~b}$ at Site 8 with those of POR2a at Site 2. As shown in the left-hand column of Table 4, POR $8 \mathrm{~b}$ admitted that she prioritized the immediate needs of the business, treated the intern (F11) as a free and convenient resource, and ignored the intern's needs. By contrast, as presented in the right-hand column, POR2a espoused having treated the internships as win-win opportunities, respected the needs and preferences of the interns (F3 and M1), and ensured that their work was challenging. The respective interns' comments confirmed that these espousals reflected contrasting levels of servant leadership behavior.

The labels in the seven rows in the middle band of Table 3 are indicative of various aspects or combinations of servant leadership behavior. Thus, "clear about internship aims" and "set challenges" imply empowering (c.f. P1); "encouraged intern to step out (of the comfort zone)" and "gave full preparation" imply helping followers grow and succeed (c.f. P2a) and putting followers first (c.f. P2b); while "available and approachable," "gave back-up support," and "supportive review and feedback" imply the POR's use of conceptual skills (c.f. P2c) and emotional healing (c.f. P2d).

The eight internships that appeared very effective and developmentally engaging (those of F1, F2, F3, F4, F6, F7, M1, and M2) also received relatively high ratings (8-13 ticks) on servant leadership by PORs, indicated by the seven rows in the middle band of Table 3. Among the five apparently moderately effective and developmentally engaging internships (those of M3, M4, F9, F10, and F12), the range of ratings on servant leadership by PORs was lower (4-11 ticks). Among the three apparently least effective and developmentally engaging 
internships (those of F5, F8, and F11), ratings on servant leadership by PORs were consistently the lowest (0-3 ticks).

One general account of the beneficial impact of a POR's servant leadership was given by M4, who perceived that empowerment and emotional healing by POR9a supported him through a positive cycle of developmental engagement, recovery, and affirmation.

I used to be afraid of failure or wasting effort, but in the internship, I was offered many opportunities to try new things and I stepped out to try new things. If something went wrong, [POR 9a] wouldn't scold me but instead would offer me great support and in due course, I had achievements. (M4, interview)

As a specific illustration, Table 5 identifies some servant leadership interventions by POR $1 \mathrm{~b}$ at Site 1, where interns F1 and F2 had been empowered to design and run classes for elderly citizens on the use of technology (they also conducted promotional events in the community). The classes did not always run smoothly, and on one occasion F1 and F2 called POR1b in to deal with complaints by some participants, who had become impatient while F1 and F2 were assisting other participants. POR1b used conceptual skills during the incident and also used emotional healing when debriefing F1 and F2 after the incident.

\section{Impact of Stakeholder Support}

Many examples were reported of contributions by other stakeholders besides PORs, which supported interns' progression through the stages of readiness, engagement, affirmation, and self-efficacy stages of development. Table 6 presents an account by intern F6 about how she engaged the support of peer interns and treasured the public reaction to her work. Table 7 illustrates how intern F3 was helped through a recovery stage by her immediate supervisor.

\section{Negative Spiraling and the Importance of Support and Encouragement}

As noted above, three internships (those of F5, F8, and F11) appeared ineffective. In these cases, absence of POR support, excessive assignment of clerical and/or technical work, scarcity of teamworking opportunities, and the respective interns' feeling of knowledge insufficiency detracted from their developmental engagement. Table 8 contains interns' accounts about their feelings of inferiority (F8), unpreparedness and fear of failure (F11), and social anxiety (F5), which appeared to perpetuate negative spirals of resource loss.

From the perspective of COR theory, it is interesting to compare the cases of F5, F8, and F11 with that of F3, who also expressed diffidence at several points during her internship, such as in the episode represented in Table 7. The difference between F3's case and those of F5, F8, and F11 is that F3 received support and encouragement from her immediate supervisor and her POR (POR2a), which appeared to restore her energy and 
developmental readiness. F3 also described her experience of being an MC at two social gatherings for recipients of surplus food:

On the first night, I was a bit nervous and so [POR2a] did most of the talking and I just backed up. [POR2a] encouraged me to talk more on the second night, so I was the only MC on the second night. [POR2a] had demonstrated how to draw the attention of the participants, so I was more confident on the second night. I still felt some fear, as everyone was looking at me, but there was a change in me. (F3, interview) 


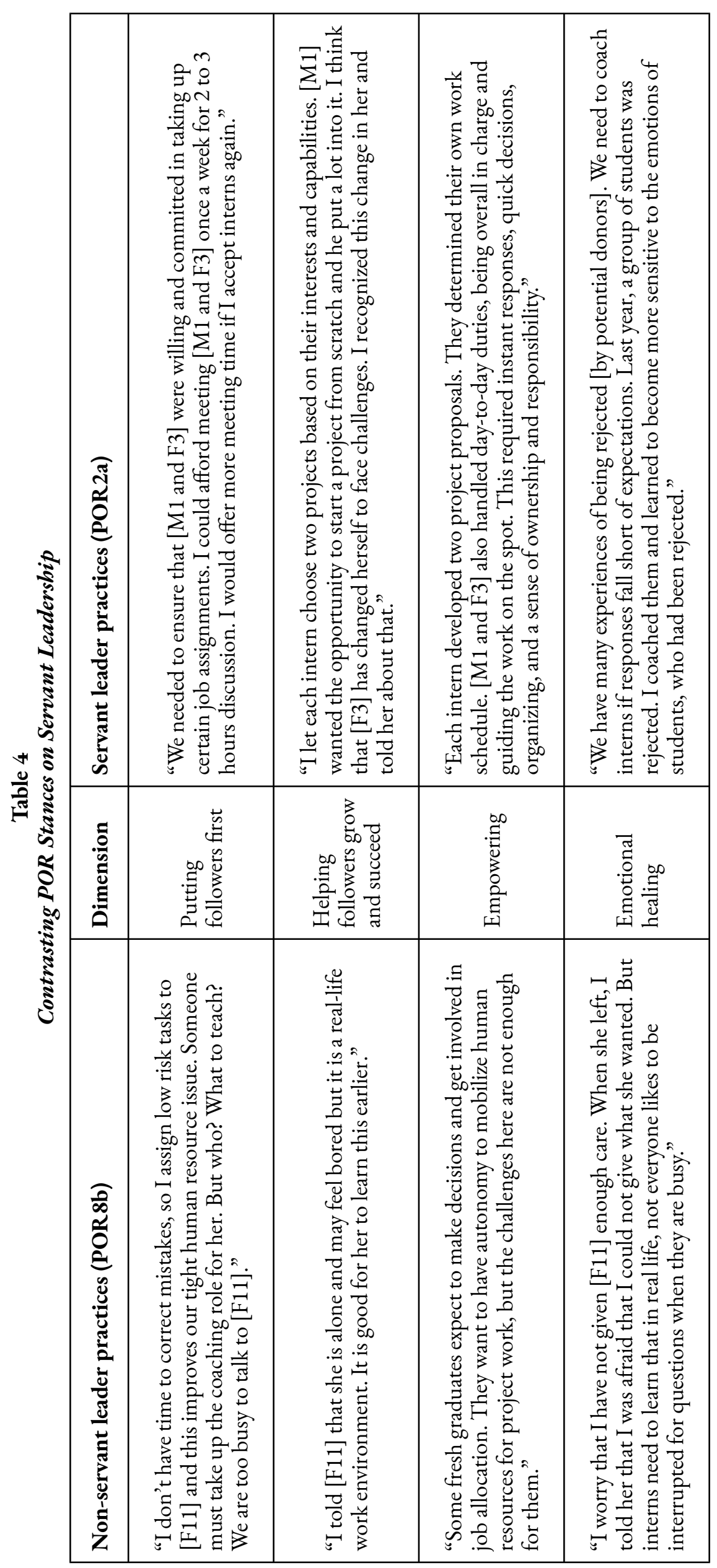




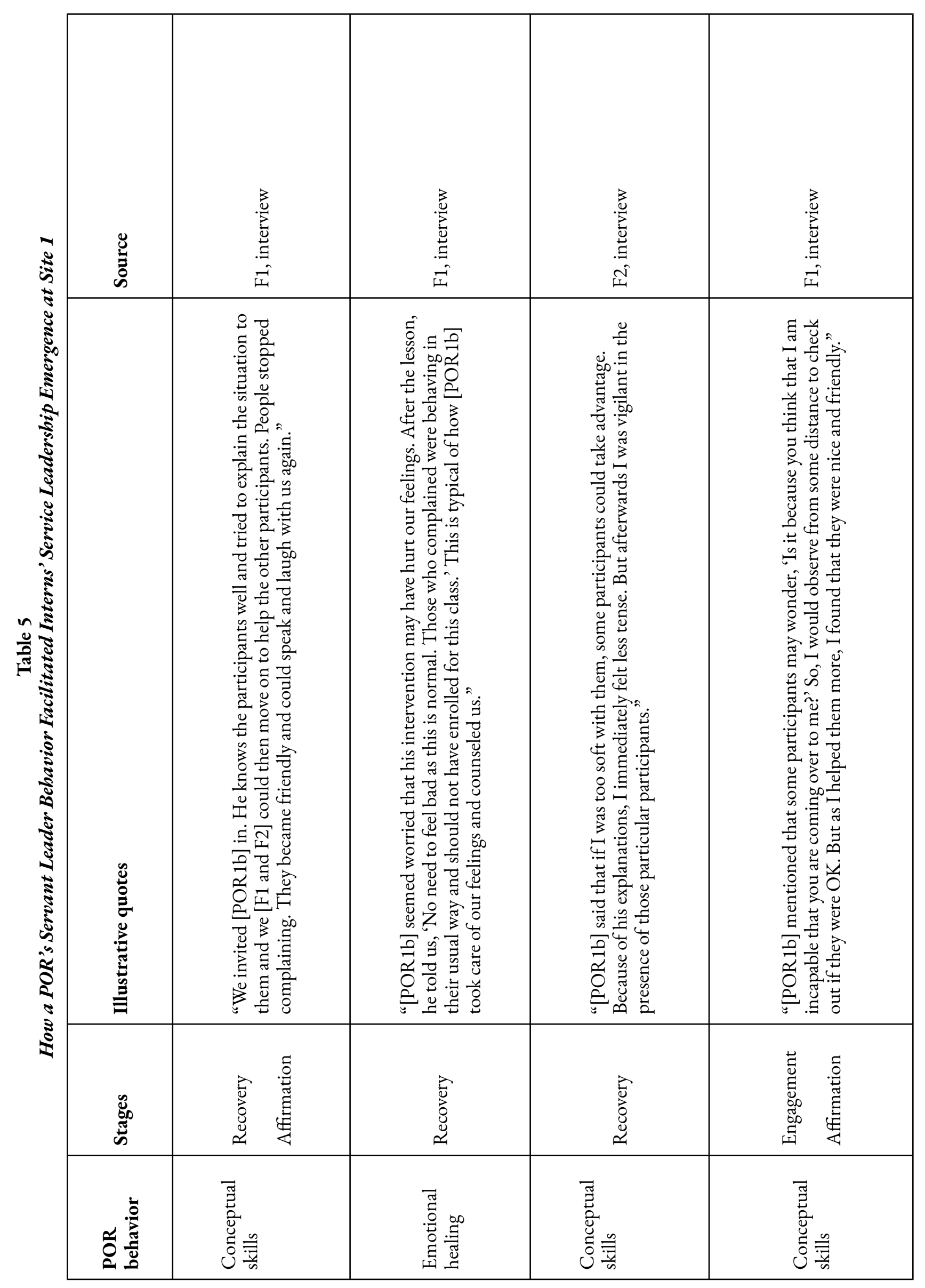




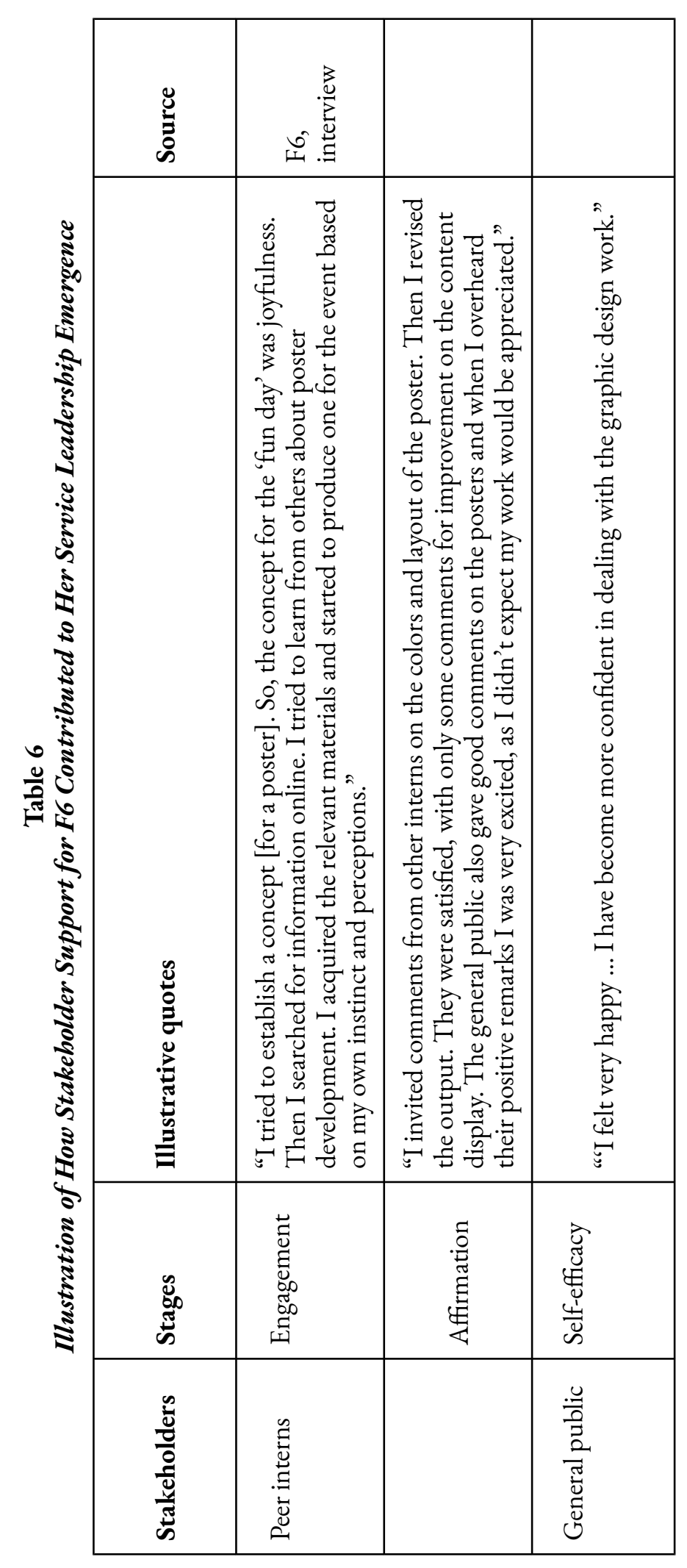




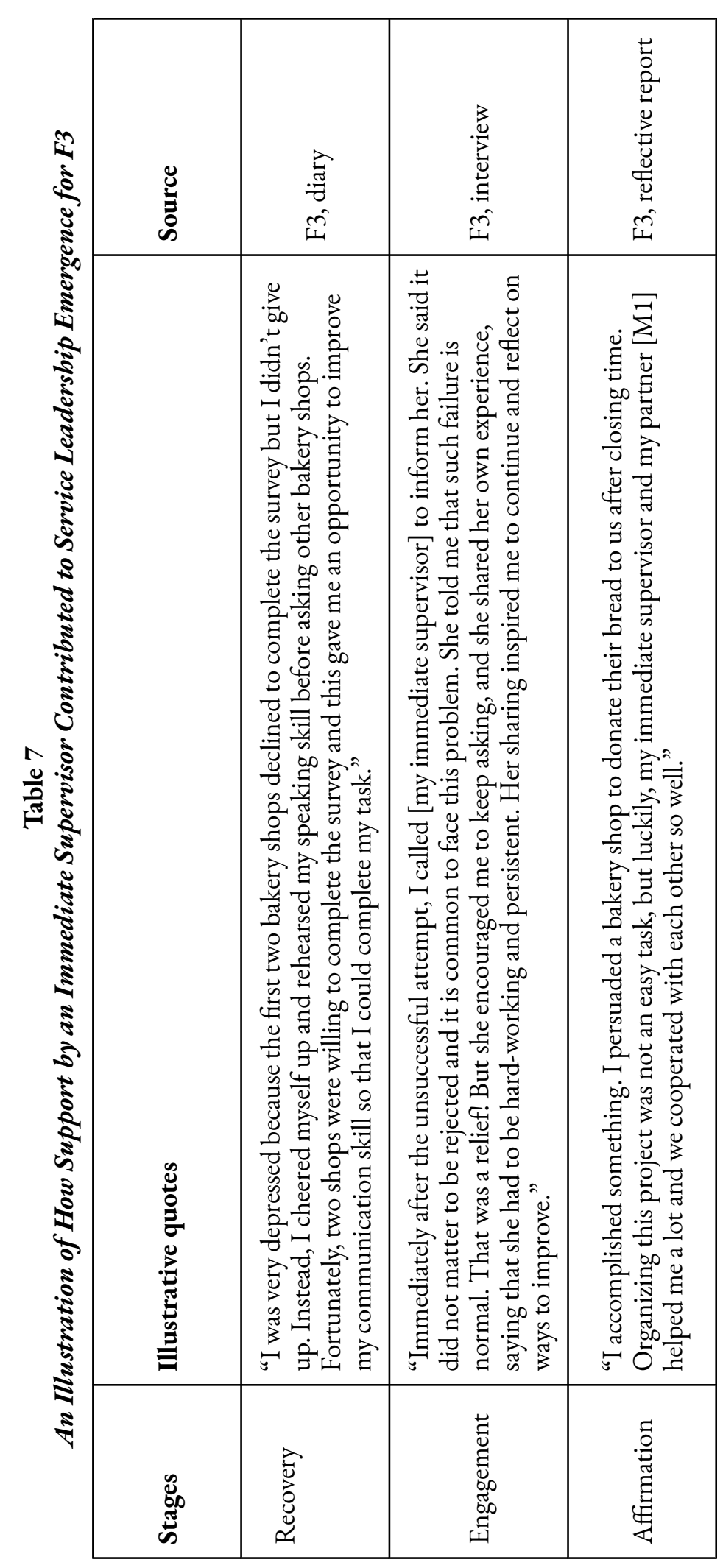




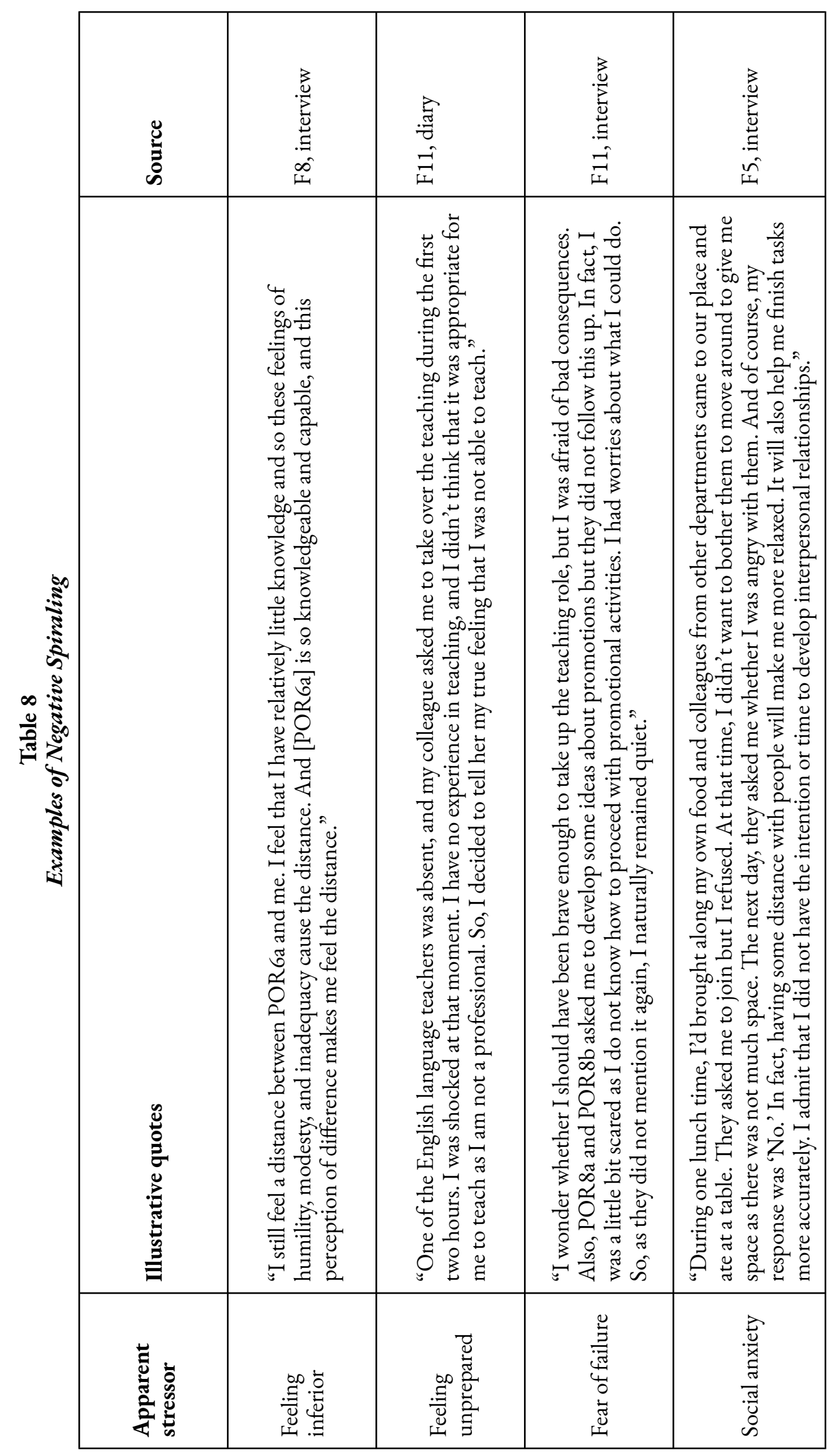




\section{Discussion and Conclusions}

The research generated four propositions about factors that support the emergence of service leadership among students participating in a service-learning-based internship program in partnership with community organizations in Hong Kong. The main factors external to an individual intern comprise empowering servant leadership by PORs, reflected in meaningful and stretching task assignments with delegated authority (c.f., P1, P4a); other types of servant leadership by PORs (c.f., P4b) that help meet interns' needs for competence (c.f., P2) and relatedness (c.f., P3); and support from peer interns and other stakeholders (c.f., P4c). The main factors internal to an intern comprise possession of a securely felt foundation of competence (P4d) and his/ her willingness to overcome challenges $(\mathrm{P} 4 \mathrm{e})$. Triangulated stories about favorable and unfavorable experiences obtained through interviews and document analysis offer broad support for the propositions. Further research could establish whether P1-4 are generalizable beyond service leadership internships to other kinds of servicelearning experiences, especially those involving direct rather than indirect service (Connor-Linton, 1995).

\section{Implications of the Research}

We have made two main theoretical contributions. The first contribution demonstrates how the SDT-based model of Chiniara and Bentein (2016) applies to the role of PORs in supporting interns' emergence as service leaders by meeting their needs for autonomy, competence, and relatedness. Our second theoretical contribution is the creation of the developmental model in Figure 2, which emerged from the data and is informed by COR as a background theory. Since the primary purpose of the research was pragmatic (Cherryholmes, 1992), our remaining remarks focus on the practical applications that have stemmed from the analysis of the 2014 data.

The need for ongoing screening of PORs and internship sites. Although resources have not been available to conduct comprehensive analysis of the experience of subsequent cohorts, data about the effectiveness of each internship continues to be collected after completion of the practicums. Post-internship interviews are held with each POR, and focus group discussions are conducted with the students, and the resulting information is used to inform quality assurance, with $\mathrm{P} 1-\mathrm{P} 4$ as key criteria. A core priority has been to initiate and maintain internship collaborations only with those PORs who appear to understand, value, and practice the co-educator role.

In addition to reviewing existing PORs and internship sites, community organizations that have already collaborated on other kinds of service-learning projects are also considered as potential sites for the internship program. Prospective PORs who have not previously participated in the internship program receive a personal briefing, in most cases delivered face-to-face, about the principles underpinning the program and about the associated requirement for PORs to serve as co-educators. Even those PORs who have collaborated on the pro- 
gram for a number of years need to be reminded to pay close attention to their co-educator role. It is also necessary through ongoing discussions with PORs to identify any changes to the agency's circumstances and the implications for the mini-missions available to the interns in future cohorts.

Credit-bearing status and longer orientation. To emphasize the academic components of the program, since 2016 the practicum program has become credit bearing, and resources became available to employ one instructor from the Management Department and one instructor from Unit S. The credit-bearing status of the practicum program has been legitimized by the expansion of the pre-internship orientation for students into a two-day workshop, parts of which are also attended by PORs. The aims of the redesigned orientation workshop are to provide a secure knowledge foundation (c.f., P4d), to align the interns' mini-missions and work assignments with the program goals of practicing and understanding service leadership attributes (c.f., P4a), and to establish rapport between interns and their PORs. The workshop includes sessions that provide fuller explanations of the attributes of service leadership (see Table 1), supported by “trigger" film clips and case scenarios for analysis and discussion. PORs introduce the background of their respective community organizations, and during a one-hour session, each student meets his or her POR to discuss plans for the internship.

Site visits by instructors. For the re-designed program, two visits by the instructors to each internship site are undertaken during the internship period to provide guidance and supervision both to the PORs and the students. Interns report their developmental progress on each of the service leadership attributes (see Table 1) and discuss any associated problems and opportunities. The instructors seek assurance that interns are not only serving the mission of the respective partner organization but also being assigned appropriate service leadership duties. For example, during one site visit, it came to light that two interns had spent much of the preceding week wheeling large trays of raw food to a kitchen location, where they cooked the food. On being confronted about this, the POR apologized and agreed that such duties should not have been assigned. In such cases, the instructors remind the POR about their co-educator role, and follow-up telephone calls are made to ensure that the POR assigns more appropriate duties.

Creation of peer learning communities. Given the importance of stakeholder support (P4c), at the orientation workshop the course instructors now launch an online learning community for each cohort using WhatsApp. Interns have used this for mutual encouragement. For example, in one cohort, at the beginning of the internship period, each intern posted photographs of their workplace and sent goodwill messages to the community. More substantively, interns have used the community as a source of practical help with problems and challenges across the different sites. For example, one intern sought ideas about how to plan a training event and received various suggestions about potential resources and activities. Another intern, who had been unable to recruit enough volunteers to support a community event, met the quota after sending a hypertext recruitment link to the WhatsApp group, which other members forwarded to their own personal contacts. Students have accordingly expressed their appreciation of the online peer community.

Screening and placing interns. The negative spiraling cases of F5, F8, and F11 suggest that a core belief in service leadership education, which holds that "everyone can be a leader" (Leung, 2015), should be revised to take account of both the context and the developmental maturity of the individual. Besides screening PORs 
and internship sites, instructors continue to screen students as an additional means of reducing the likelihood of negative spiraling.

Another practical consideration concerns the degree to which interns feel that they have a sufficiently secure domain-specific knowledge foundation to assume service leadership responsibilities. For example, F1 and F2 felt confident about designing and providing training to elderly people about information technology because their prior studies had introduced them to the needs and concerns of elderly people. By contrast, F8 and F11 were inhibited because of their self-perceived knowledge gaps. It is important to identify major domain-specific knowledge demands in advance in order to avoid mismatches between interns and placements.

Limitations. The findings are based on a Hong Kong-based internship program with a relatively small sample. This may limit the generalizability of the research findings. Our study nonetheless provides insights to further explore how to internally motivate students and how to create and maintain desirable conditions to support students' leadership development. Another limitation is that we do not specifically analyze the impact of students' previous domain knowledge and service-learning experience on their current internship performance. Future research may explore more on this aspect.

\section{References}

Atkinson, R. D. (2004). The past and future of America's economy: Long waves of innovation that power cycles of growth. Cheltenham, UK: Edward Elgar.

Avolio, B. J., \& Hannah, S. T. (2008). Developmental readiness: Accelerating leader development. Consulting Psychology Journal: Practice and Research, 60(4), 331-347.

Ayres, J., \& Malouff, J. M. (2007). Problem-solving training to help workers increase positive affect, job satisfaction, and life satisfaction. European Journal of Work and Organizational Psychology, 16(3), 279-294.

Bakker, A. B., \& Demerouti, E. (2008). Towards a model of work engagement. Career Development International, 13(3), 209-223.

Bandura, A. (1986). Social foundations of thought and action: A social cognitive theory. Englewood Cliffs, NJ: Prentice Hall.

Baumeister, R. F., \& Leary, M. R. (1995). The need to belong: Desire for interpersonal attachments as a fundamental human motivation. Psychological Bulletin, 117(3), 497-529.

Beard, D. F. (2007). Assessment of internship experiences and accounting core competencies. Accounting Education, 16(2), 207-220.

Bitner, M. J., Booms, B. H., \& Mohr, L. A. (1994). Critical service encounters: The employee's viewpoint. Journal of Marketing, 58(4), 95-106.

Boje, D. M. (2001). Narrative methods for organizational $\sigma^{2}$ communication research. London, UK: Sage Publications. 
Bringle, R. G., Studer, M., Wilson, J., Clayton, P. H., \& Steinberg, K. S. (2011). Designing programs with a purpose: To promote civic engagement for life. Journal of Academic Ethics, 9(2), 149-164.

Cherryholmes, C. H. (1992). Notes on pragmatism and scientific realism. Educational Researcher, 21(6), 13-17.

Chiniara, M., \& Bentein, K. (2016). Linking servant leadership to individual performance: Differentiating the mediating role of autonomy, competence and relatedness need satisfaction. The Leadership Quarterly, 27(1), 124-141.

Chow, J. M.-L., \& Lam, S.-F. (2015). Nurturing leadership and changing student mindset through meaningful community service: The HKU service leadership internship. In D. T. L. Shek \& P. Chung (Eds.), Promoting service leadership qualities in university students: The case of Hong Kong (pp. 67-81). Singapore: Springer.

Chung, P. (2012). Service reborn: The knowledge, skills and attributes of service companies. Tiburon, CA: Lexingford.

Clark, S. C. (2003). Enhancing the educational value of business internships. Journal of Management Education, $27(4), 472-484$.

Coco, M. (2000). Internships: A try before you buy arrangement. SAM Advanced Management Journal, $65(2), 41-43,47$.

Connor-Linton, J. (1995). An indirect model of service-learning: Integrating research, teaching, and community service. Michigan Journal of Community Service Learning, 2(1), 105-111.

Cook, S. J., Parker, R. S., \& Pettijohn, C. E. (2004). The perceptions of interns: A longitudinal case study. Journal of Education for Business, 79(3), 179-185.

Creswell, J. W. (2013). Qualitative inquiry and research design: Choosing among five approaches (3rd ed.). Thousand Oaks, CA: Sage Publications.

Cunliffe, A. L. (2009). The philosopher leader: On relationalism, ethics and reflexivity-A critical perspective to teaching leadership. Management Learning, 40(1), 87-101.

D’Abate, C. P., Youndt, M. A., \& Wenzel, K. E. (2009). Making the most of an internship: An empirical study of internship satisfaction. Academy of Management Learning $\Xi^{2}$ Education, 8(4), 527-538.

Debeljuh, P., \& Destefano, A. (2005). An inside look into teaching corporate social responsibility: A practical study with NGOs. Journal of Business Ethics Education, 2(2), 137-150.

Deci, E. L. (1971). Effects of externally mediated rewards on intrinsic motivation. Journal of Personality and Social Psychology, 18(1), 105-115.

Deci, E. L., \& Ryan, R. M. (2000). The "what" and "why” of goal pursuits: Human needs and the self-determination of behavior. Psychological Inquiry, 11(4), 227-268.

Deci, E. L., Vallerand, R. J., Pelletier, L. G., \& Ryan, R. M. (1991). Motivation and education: The self-determination perspective. Educational Psychologist, 26(3/4), 325-346.

Deci, E. L., \& Vansteenkiste, M. (2004). Self-determination theory and basic need satisfaction: Understanding human development in positive psychology. Ricerche di Psicologia, 27(1), 23-40. 
Degravel, D. (2011). Internships and small business: A fruitful union? A conceptual approach. Journal of Management Policy and Practice, 12(2), 27-43.

Ehrhart, M. G. (2004). Leadership and procedural justice climate as antecedents of unit-level organizational citizenship behavior. Personnel Psychology, 57(1), 61-94.

Fung, V. (2015). Development of the service economy in Hong Kong: Challenges and opportunities. In D. T. L. Shek \& P. Chung (Eds.), Promoting service leadership qualities in university students: The case of Hong Kong (pp. xi-xiii). Singapore: Springer.

Gabriel, Y. (2000). Storytelling in organizations: Facts, fictions, and fantasies. Oxford, UK: Oxford University Press.

Gagné, M., \& Deci, E. L. (2005). Self-determination theory and work motivation. Journal of Organizational Behavior, 26(4), 331-362.

George, J. M. (2000). Emotions and leadership: The role of emotional intelligence. Human Relations, 53(8), 1027-1055.

Godfrey, P. C., Illes, L. M., \& Berry, G. R. (2005). Creating breadth in business education through servicelearning. Academy of Management Learning E。 Education, 4(3), 309-323.

Grant, A. (2013). Give and take: A revolutionary approach to success. New York, NY: Viking Press.

Greenleaf, R. K. (1977). Servant leadership: A journey into the nature of legitimate power and greatness. Mahway, NJ: Paulist Press.

Greenleaf, R. K., Beazley, H., Beggs, J., \& Spears, L. C. (2003). The servant-leader within: A transformative path. Mahwah, NJ: Paulist Press.

Grönfeldt, S., \& Strother, J. (2006). Service leadership: The quest for competitive advantage. Thousand Oaks, CA: Sage Publications.

Halbesleben, J. R. B., \& Wheeler, A. R. (2008). The relative roles of engagement and embeddedness in predicting job performance and intention to leave. Work E'Stress, 22(3), 242-256.

Hallberg, L. R.-M. (2006). The "core category" of grounded theory: Making constant comparisons. International Journal of Qualitative Studies on Health and Well-Being, 1(3), 141-148.

Hobfoll, S. E. (1985). Personal and social resources and the ecology of stress resistance. In P. Shaver (Ed.), Review of Personality and Social Psychology: Vol. 6. Self, situations, and social behavior (pp. 265-290). Beverly Hills, CA: Sage.

Hobfoll, S. E. (1989). Conservation of resources: A new attempt at conceptualizing stress. American Psychologist, 44(3), 513-524.

Hobfoll, S. E. (2001). The influence of culture, community, and the nested-self in the stress process: Advancing conservation of resources theory. Applied Psychology, 50(3), 337-421.

Hobfoll, S. E. (2002). Social and psychological resources and adaptation. Review of General Psychology, 6(4), 307-324.

Hobfoll, S. E., \& Lilly, R. S. (1993). Resource conservation as a strategy for community psychology. Journal of Community Psychology, 21(2), 128-148. 
Holyoak, L. (2013). Are all internships beneficial learning experiences? An exploratory study. Education and Training, 55(6), 573-583.

Hoshmand, A. R. (2015). The role of service leadership in the University's GE curriculum: The HKBU experience. In D. T. L. Shek \& P. Chung (Eds.), Promoting service leadership qualities in university students: The case of Hong Kong (pp. 17-28). Singapore: Springer.

Howard, J. (Ed.). (2001). Service-learning course design workbook. Michigan Journal of Community Service Learning, companion volume.

Jit, R., Sharma, C. S., \& Kawatra, M. (2016). Servant leadership and conflict resolution: A qualitative study. International Journal of Conflict Management, 27(4), 591-612.

Jonsen, K., \& Jehn, K. A. (2009). Using triangulation to validate themes in qualitative studies. Qualitative Research in Organizations and Management, 4(2), 123-150.

Kenworthy-U'Ren, A. L. (2003). Service-learning and negotiation: Engaging students in real-world projects that make a difference. Negotiation Journal, 19(1), 51-63.

Knemeyer, A. M., \& Murphy, P. R. (2002). Logistics internships: Employer and student perspectives. International Journal of Physical Distribution E' Logistics Management, 32(2), 135-152.

Kvale, S. (1996). Interviews: An introduction to qualitative research interviewing. Thousand Oaks, CA: Sage Publications.

Leech, N. L., \& Ongwuegbuzie, A. J. (2008). Qualitative data analysis: A compendium of techniques and a framework for selection for school psychology research and beyond. School Psychology Quarterly, 23(4), 587-604.

Leung, L. M. K. (2015). The construction of student leadership development model in HKIEd: Based on Service leadership core beliefs advocated by HKI-SLAM. In D. T. L. Shek \& P. Chung (Eds.), Promoting service leadership qualities in university students: The case of Hong Kong (pp. 83-97). Singapore: Springer.

Liden, R. C., Wayne, S. J., Zhao, H., \& Henderson, D. (2008). Servant leadership: Development of a multidimensional measure and multi-level assessment. The Leadership Quarterly, 19(2), 161-177.

Miles, M. B., \& Huberman, A. M. (1994). Qualitative data analysis: An expanded sourcebook (2nd ed.). Thousand Oaks, CA: Sage Publications.

Nelis, D., Kotsou, I., Quoidbach, J., Hansenne, M., Weytens, F., Dupuis, P., \& Mikolajczak, M. (2011). Increasing emotional competence improves psychological and physical well-being, social relationships, and employability. Emotion, 11(2), 354-366.

Papamarcos, S. D. (2005). Giving traction to management theory: Today's service-learning. Academy of Management Learning E' Education, 4(3), 325-335.

Ross, L. E., \& Elechi, O. O. (2002). Student attitudes towards internship experiences: From theory to practice. Journal of Criminal Justice Education, 13(2), 297-312.

Rost, J. C. (1991). Leadership for the twenty-first century. Westport, CT: Praeger.

Rost, J. C. (1994). Leadership: A new conception. Holistic Nursing Practice, 9(1), 1-8. 
Rothman, M. (2003). Internships: Most and least favored aspects among a business school sample. Psychological Reports, 93(3), 921-924.

Rothman, M. (2007). Lessons learned: Advice to employers from interns. Journal of Education for Business, $82(3), 140-144$.

Ryan, R. M., \& Deci, E. L. (2006). Self-regulation and the problem of human autonomy: Does psychology need choice, self-determination, and will? Journal of Personality, 74(6), 1557-1586.

Ryan, R. M., \& Deci, E. L. (2008). From ego depletion to vitality: Theory and findings concerning the facilitation of energy available to the self. Social and Personality Psychology Compass, 2(2), 702-717.

Sabbaghi, O., Cavanagh, G. F., \& Hipskind, T. (2013). Service-learning and leadership: Evidence from teaching financial literacy. Journal of Business Ethics, 118(1), 127-137.

Schaubroeck, J., Lam, S. S. K., \& Peng, A. C. (2011). Cognition-based and affective-based trust as mediators of leader behavior influence on team performance. Journal of Applied Psychology, 96(4), 863-871.

Schaufeli, W., \& Salanova, M. (2005). Work engagement: An emerging psychological concept and its implications for organizations. In S. W. Gilliland, D. D. Steiner, \& D. P. Skarlicki (Eds.), Research in Social Issues in Management: Vol. 5. Managing social and ethical issues in organizations (pp. 135-177). Greenwich, CT: Information Age Publishers.

Scheuer, C.-L., \& Mills, A. J. (2016). Discursivity and media constructions of the intern: Implications for pedagogy and practice. Academy of Management Learning $\Xi^{2}$ Education, 15(3), 456-470.

Segrin, C., \& Taylor, M. (2007). Positive interpersonal relationships mediate the association between social skills and psychological well-being. Personality and Individual Differences, 43(4), 637-646.

Shek, D. T. L., \& Chung, P. (2015). Service leadership education for university students: Seven unfinished tasks. In D. T. L. Shek \& P. Chung (Eds.), Promoting service leadership qualities in university students: The case of Hong Kong (pp. 225-232). Singapore: Springer.

Shek, D. T. L., Chung, P. P. Y., \& Leung, H. (2015). How unique is the service leadership model? A comparison with contemporary leadership approaches. International Journal on Disability and Human Development, 14(3), 217-231.

Shek, D. T. L., \& Leung, H. (2015). Service leadership qualities in university students through the lens of student well-being. In D. T. L. Shek \& P. Chung (Eds.), Promoting service leadership qualities in university students: The case of Hong Kong (pp. 1-16). Singapore: Springer.

Sheldon, K. M., Ryan, R. M., \& Reis, H. T. (1996). What makes for a good day? Competence and autonomy in the day and in the person. Personality and Social Psychology Bulletin, 22(12), 1270-1279.

Smith, C., \& Chan, J. (2015). Working for two bosses: Student interns as constrained labour in China. Human Relations, 68(2), 305-326.

Solansky, S. T. (2015). Self-determination and leader development. Management Learning, 46(5), 618-635.

Spears, L. C. (2004). The understanding and practice of servant leadership. In L. C. Spears \& M. Lawrence (Eds.), Practicing servant leadership: Succeeding through trust, bravery, and forgiveness (pp. 9-24). San Francisco, CA: Jossey-Bass. 
Spears, L. C. (2010). Character and servant leadership: Ten characteristics of effective, caring leaders. Journal of Virtues and Leadership, 1(1), 25-30.

Stuart, R. (1978). Contracting to learn: A perspective on the dynamics of management development activities. Management Education and Development, 9(2), 75-84.

Trompenaars, A., \& Voerman, E. (2010). Servant-leadership across cultures: Harnessing the strength of the world's most powerful management philosophy. New York, NY: McGraw-Hill.

van Dierendonck, D. (2011). Servant leadership: A review and synthesis. Journal of Management, 37(4), $1228-1261$.

Van Knippenberg, D., \& Van Schie, E. C. M. (2000). Foci and correlates of organizational identification. Journal of Occupational and Organizational Psychology, 73(2), 137-147.

Woodside, M. (2017). The buman services internship experience: Helping students find their way. Thousand Oaks, CA: Sage Publications.

Yin, R. K. (2009). Case study research: Design and method (4th ed.). Thousand Oaks, CA: Sage Publications.

Zhang, Q. (2013). Students' expectations and perceptions of internship programs: The example of China-Beijing BIEM students in Continental-grand hotel for internship. Advances in Management and Applied Economics, 3(6), 217-222.

Zhou, C., Chan, B. Y. B., \& Mickleborough, N. C. (2015). Why is service leadership important in higher education? In D. T. L. Shek \& P. Chung (Eds.), Promoting service leadership qualities in university students: The case of Hong Kong (pp. 135-138). Singapore: Springer.

\section{Authors}

ROBIN STANLEY SNELL is a Professor in the Department of Management at Lingnan University. An exponent of qualitative research methodology, Professor Snell has completed several funded projects in the areas of managerial and organizational learning and business ethics. His work has been published in many journals, including Asia Pacific Journal of Management, British Journal of Management, Business Ethics Quarterly, Human Relations, Human Resource Management Journal, International Business Review, Journal of Business Ethics, Journal of Management Development, Journal of Management Education, Journal of World Business, Management Learning, and Organization Studies.

MAUREEN YIN-LEE CHAN is a Student Development Manager in the Student Affairs Office at The Education University of Hong Kong. She obtained a PhD in Management Learning and Leadership from Lancaster University in the UK and has extensive practitioner experience in the field of human resource development. She has published papers on service leadership development in the Asian Journal of Business Ethics, Journal of Management Education, and Leadership E Organization Development Journal. 
CRYSTAL XINRU WU is a doctoral student in the Department of Management at Lingnan University. Her areas of interest are conflict management and servant leadership.

CONSTANCE WING-YEE CHAN is a Teaching Fellow in the Office of Service-Learning at Lingnan University. She is currently a PhD candidate at the National Cheng Kung University in Taiwan. Her teaching interests are community engagement through service-learning. Her research interests are social capital and knowledge production in service-learning. She is a registered social worker. 